\section{Original Research}

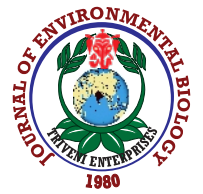

DOI : http://doi.org/10.22438/jeb/415(SI)/MS_32
Journal Home page : www.jeb.co.in $\star$ E-mail : editor@jeb.co.in Journal of Environmental Biology

p-ISSN: 0254-8704 e-ISSN: 2394-0379 CODEN: JEBIDP

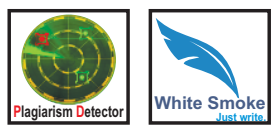

\title{
Species composition and diversity of fishes from the seagrass habitat of Lawas, Sarawak, Malaysia
}

\author{
I. Johan ${ }^{1}$, M.K. Abu Hena ${ }^{2 *}$, M.H. Idris', S.M.N. Amin ${ }^{3}$, N.A. Denil', U. Kumar ${ }^{1}$ and N.U. Karim ${ }^{2}$ \\ 'Department of Animal Science and Fisheries, Faculty of Agriculture and Food Sciences, Universiti Putra Malaysia Bintulu Campus, 97008 Bintulu \\ Sarawak, Malaysia \\ ${ }^{2}$ Faculty of Fisheries and Food Science, Universiti Malaysia Terengganu, 21030 Kuala Nerus, Terengganu, Malaysia \\ ${ }^{3}$ Department of Aquaculture, Faculty of Agriculture, Universiti Putra Malaysia, 43400 UPM Serdang, Selangor, Malaysia \\ *Corresponding Author Email : a.hena@umt.edu.my
}

\section{Abstract}

Aim: To investigate the species composition and diversity of fishes from the seagrass habitat in Lawas, Sarawak, Malaysia.

Methodology: Fishes were collected with an encircling gillnet net during the dry, wet and intermediate season of the year. Water characteristics were analyzed in-situ through analytical methods.

Results: A total of 60 fish species from 37 families were recorded in the seagrass ecosystem. Dominant species with highest total abundance observed were Lethrinus lentjan (12.83\%), Hyporhamphus limbatus (8.50\%) and Leiognathus equulus (8.33\%). Cluster analysis revealed three fish species assemblages; Lethrinus lentjan and Lutjanus fulviflamma (dry season), Nibea soldadu, Platycephalus indicus and L. equulus (intermediate season), while Hyporhamphus limbatus, Gerres erythrourus, Thryssa hamiltonii, Gerres oyena, Sphyraena jello and Gnathanodon speciosus (wet-intermediate season). All indices (no. of species, diversity and evenness) showed an increasing trend from dry, wet to intermediate season.

Interpretation: The seagrass ecosystem of Lawas harbours a rich and diverse group of fish communities indicating an important fishery resource habitat. The findings of this study provide baseline information on fish resources from this seagrass ecosystem, which will be useful for the conservation and management of its fish resources in the future.

Key words: Fish diversity, Important species indices, Seagrass ecosystem, Species composition

To investigate the species composition and diversity of fishes from the seagrass habitat in Lawas, Sarawak, Malaysia
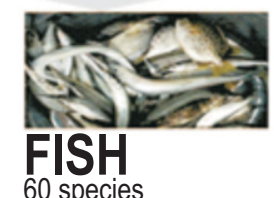

37 families

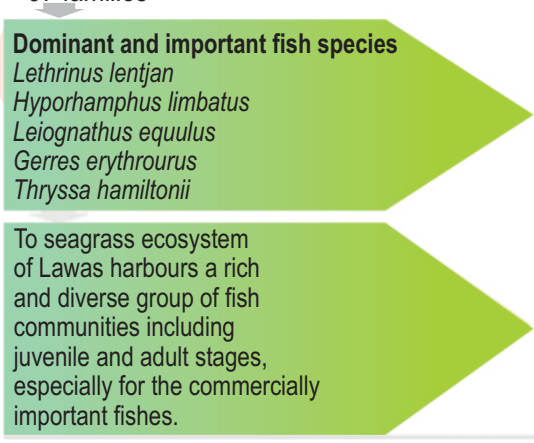

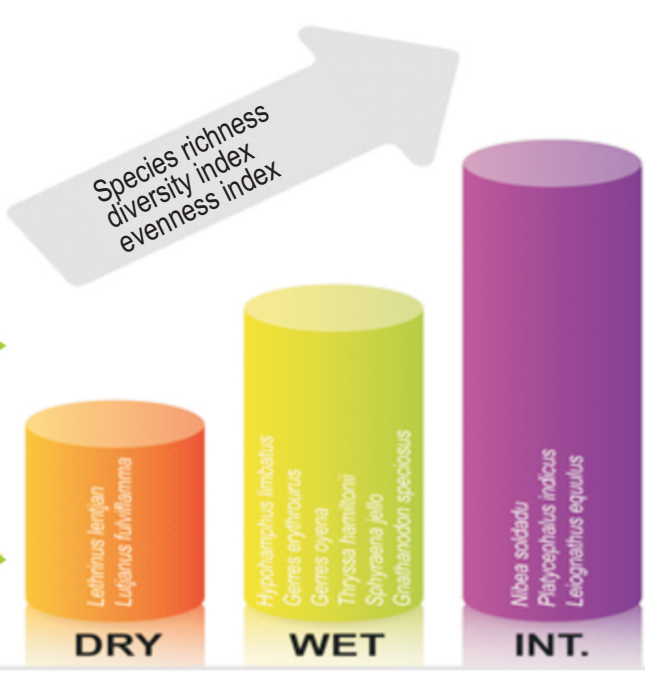

How to cite : Johan, I., M.K. Abu Hena, M.H. Idris, S.M.N. Amin, N.A. Denil, U. Kumar and N.U. Karim: Species composition and diversity of fishes from the seagrass habitat of Lawas, Sarawak, Malaysia. J. Environ. Biol., 41, 1382-1389 (2020). 


\section{Introduction}

Seagrass beds have extremely high primary and secondary productivity, which support a great abundance and diversity of fishery resources. In seagrass ecosystem, many local coastal communities catch fish and other biological resources for their livelihood. It is well established that seagrass beds are excellent feeding and nursery habitats of many fishes and invertebrates during their juvenile stages, due to high abundance of food and low predation pressure (Huijibers et al., 2008). Many fish species, especially juveniles and those at larval stage inhabit seagrass beds throughout their entire life history (Browyn, 2006). The distribution and abundance of fish larvae of different size range throughout a year confirmed the continuous spawning activity of larvae in seagrass beds (Ara et al., 2011). Seagrass beds can support a great abundance and diversity of marine invertebrates because of higher organic content in the area (Zaleha et al., 2015). Furthermore, seagrass form the food and habitats for the vulnerable dugongs, seahorses and endangered green and hawksbill turtles, as well as other fishes. The seagrass ecosystem also acts as a feeding ground for seasonal migratory birds (Japar et al., 2006; Juanita et al., 2017; Mazlan et al., 2017).

In Malaysia, the studies on seagrass ecosystems and functions are mainly based on seagrass beds found in Peninsular Malaysia. The seagrass beds have been documented to harbor diverse fish species and important commercial fishes (Arshad et al., 2001; Arshad et al., 2006), diverse and abundant icthyoplankton (Ara et al., 2013), post-larval shrimps (Arshad et al., 2011), diverse microbenthic communities (Wong et al., 2014), and abundance of zooplankton (Mathias and Yusoff, 2015). Among the commercial fish species inhabiting these seagrass habitats are llisha spp., Stolephorus indicus, Thryssa hamiltoni, Hippocampus spp., Lates calcarifer, Lutjanus chrysotaenia, Plotosus canius, Apolyne mussextarius, Rastrelliger kanaqurta, Siganus guttatus, S. javus, Siganus sp., Epinephalus sp. and Therapon spp. (Arshad et al., 2001). Major families of icthyoplankton that occurr consistently in the seagrass habitats around the year are Clupeidae, Terapontidae, Nemipteridae, Sillaginidae, Blenniidae and Gobiidae (Ara et al., 2013), while the major post larval shrimp recorded in the habitats are Lucifer, Acetes, Peneaus and Mysis (Arshad et al., 2011).

There are 78 recorded sites of seagrass beds, scattered in the west and east coasts of Peninsular Malaysia and, Sabah and Sarawak in East Malaysia. The largest seagrass bed is in Sarawak (240 ha), followed by Johor (112 ha), Terengganu (105 ha), Kelantan (87 ha) and Negeri Sembilan (11 ha) (Japar and Muta Harah, 2011). The seagrass bed in Sarawak occurs only at a single location in Lawas making it the single largest seagrass bed in Malaysia, and still considered in pristine condition. Eight seagrass species has been recorded in Lawas (Abu Hena et al., 2016; Japar et al., 2006; Ahmad Kamil et al., 2013). Information on other ecosystem components from the Lawas seagrass beds such as fish resources are not well documented. Keeping in view the above this study was conducted with the aim to determine the seasonal diversity and abundance of fish communities in the seagrass ecosystem of Lawas, Sarawak and its relation to physico-chemical parameters.

\section{Materials and Methods}

The seagrass bed in Lawas $\left(4^{\circ} 55^{\prime} 26.6^{\prime \prime} \mathrm{N}, 115^{\circ} 23^{\prime} 30.0^{\prime \prime}\right.$ E) is located on the south eastern corner of South China Sea, within the Brunei Bay (Fig. 1). The seagrass bed is approximately $15 \mathrm{~km}$ to the small town of Lawas, North Sarawak, bordering Sabah (33 km) and Brunei $(25 \mathrm{~km})$. The coastal communities comprise small-scale fisherman in Lawas established in Kampung Punang, Kampung Kuala Lawas and Kampung Awatawat. Eight species of seagrass have been recorded in the study area, i.e. Halodule pinifolia, Halodule uninervis, Halophila ovalis, Halophila minor, Halophila beccarii, Cymodocearo tundata, Enhalus acroides and Thalassia hemprichii (Japar et al., 2006; Ahmad Kamil et al., 2013). The seagrass bed in Lawas is adjacent to a mangrove forest reserve dominated by mangrove species such as Avicennia sp., Bruguiera parviflora, B. sexangula, Lumnitzera racemosa, L. littorea, Nypa fruticans, Rhizophora apiculata, R. mucronata, Sonneratia alba, S. caseolaris and Xylocarpus granatum (Gandaseca et al., 2014).

The study area experience three seasonal monsoon patterns: intermediate (January till April), dry (May till August) and wet (September till December). The average total monthly rainfall in the area is $244.17 \mathrm{~mm}$. The highest average total monthly rainfall recorded during the intermediate season $(250.40 \mathrm{~mm})$, followed by wet season $(235.75 \mathrm{~mm}$ ) and dry season (206.30 $\mathrm{mm})$. Batang Lawas, Sungai Punang, Sungai Sangkurum, Sungai Siang-Siang and Sungai Bangat are the major rivers

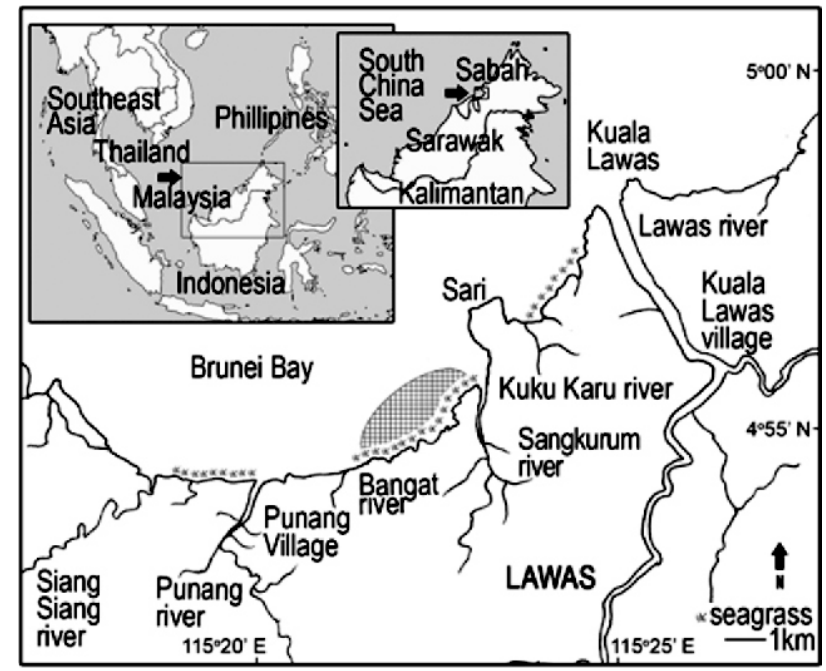

Fig. 1 : Geographical location of sampling area (shaded) at seagrass beds in Lawas, Sarawak. 
flowing in the study area.

Water $\mathrm{pH}$, temperature, salinity, turbidity, conductivity and dissolved oxygen were recorded in situ with Hydrolab DS5X multiparameter water quality sonde. In addition, triplicate surface water samples were collected from the sampling location for further analysis. The water samples were brought to the laboratory and tested for dissolved inorganic phosphate following ascorbic acid method, and ammonia following Phenate method (APHA, 2017) and chlorophyll a following spectrophotometric method, nitrate following hydrazine reduction method (Kitamura et al., 1982). Rainfall data were obtained from the Meteorological Department of Malaysia (2016-2017).

The fishes were collected using a gill net of mesh size of $4.45 \mathrm{~cm}$, length of $152 \mathrm{~m}$ and a depth of $1.8 \mathrm{~m}$. Three sampling exercises were conducted, once during each season. The gill net was deployed six times at the seagrass bed during each sampling effort each season. The sampling of fish was carried out with the fisherman by employing the encircling gillnet fishing method (Beare and Tanimomo, 1991). The fishes caught were preserved in $10 \%$ formalin and then processed for identification, measurement of total length and weight. Fish specimens were identified upto species level based as per available literature (Ambak et al., 2010; Azmi et. al., 2010; Carpenter and Niem, 1999; Carpenter and Niem, 2001; Mansor et al., 1998; Matsunuma et al., 2011; Mohsin and Ambak, 1996).

Important Species Indices (ISIs) were calculated for each taxon at all sampling sites according to Rushforth and Brock (1991). The diversity of fish community was expressed in terms of Shannon-Wiener diversity index $\left(\mathrm{H}^{\prime}\right)$ and Shannon's equitability evenness index $\left(E_{H}\right)$ (Shannon and Weaver, 1963). Cluster analysis was conducted using log-transformed percentage data of fish by Minimum Variance method with Squared Euclidian distance. One-way ANOVA was carried out to determine the seasonal variation of different physico-chemical parameters. Pearson's correlation coefficient was calculated to characterize relationship between biotic and abiotic parameters. Analysis was done using SPSS version 16.0 and Multivariate Statistical Package (MVSP Ver3.13, Kovach, 1999).

\section{Results and Discussion}

The results of physico-chemical parameters of seawater found in this study is presented in Table 1 . The $\mathrm{pH}$ ranged between 6.36 (dry season) to 7.92 (dry and intermediate season). The lowest $\left(26.56^{\circ} \mathrm{C}\right)$ and highest temperature $\left(31.63^{\circ} \mathrm{C}\right)$ was recorded during dry season. Salinity varied from 25.67 to 29.35 PSU, with the lowest salinity recorded in the intermediate season and the highest during dry season. Dissolved oxygen was highest during the intermediate season $\left(6.71 \mathrm{mgl}^{-1}\right)$ while the lowest DO was recorded during dry season $\left(5.00 \mathrm{mg} \mathrm{l}^{-1}\right)$. Dissolved oxygen varied significantly $(p<0.05)$ within the seasons. The concentration of dissolved oxygen was influenced by photosynthetic plant and algal biomass, light intensity and water temperature, and are subject to diurnal and seasonal variations (Connell and Miller, 1988). Low salinity, temperature and dissolved oxygen during intermediate-wet season in Lawas was also observed in Sungai Pulai seagrass beds, showing similar seasonal effects on both seagrass beds (Mathias and Yusoff, 2014). The lowest (10.2 NTU) and the highest (106.40 NTU) turbidity was recorded during intermediate season.

For water nutrients, ammonia concentrations were significantly different within the seasons $(p<0.05)$. Ammonia was highest during dry season $\left(0.54 \mathrm{mg}^{-1}\right)$ and lowest during intermediate season $\left(0.10 \mathrm{mgl}^{-1}\right)$. Chlorophyll a was found higher during dry season $\left(1.84 \mathrm{mg} \mathrm{m}^{-3}\right)$ and lower during intermediate season $\left(0.06 \mathrm{mg} \mathrm{m}^{-3}\right)$. The seasonal pattern of chlorophyll a in this study was similar to Kuala Sibuti river, while higher concentrations were recorded during dry season (Saifullah et al., 2014). Distribution of nutrients is mainly influenced by seasonal variation, rate of fresh water discharge, land run-off and tidal condition (Nirmalkumar et al., 2009).

A total of 600 fish specimens were recorded in the seagrass ecosystem, comprising 60 fish species from 37 families

Table 1 : Mean values of different physico-chemical parameters recorded in different seasons in seagrass bed of Lawas, Sawark

\begin{tabular}{llll}
\hline Parameter/Season & Dry & Wet & Intermediate \\
\hline pH & $7.51 \pm 0.47$ & $7.72 \pm 0.02$ & $7.88 \pm 0.35$ \\
Temperature $\left({ }^{\circ} \mathrm{C}\right)$ & $29.26 \pm 1.47$ & $29.79 \pm 0.29$ & $27.03 \pm 0.14$ \\
Salinity $(\mathrm{PSU})$ & $28.22 \pm 0.57$ & $27.31 \pm 0.51$ & $25.63 \pm 0.04$ \\
Conductivity $\left(\mathrm{mS} \mathrm{cm}{ }^{-1}\right)$ & $43.38 \pm 1.66$ & $42.47 \pm 0.72$ & $40.10 \pm 0.05$ \\
Turbidity $(\mathrm{NTU})$ & $45.17 \pm 8.41$ & $28.83 \pm 1.48$ & $52.90 \pm 28.29$ \\
Dissolved oxygen $\left(\mathrm{mgl}^{-1}\right)$ & $5.22 \pm 0.19 \mathrm{a}$ & $5.31 \pm 0.05 \mathrm{a}$ & $6.66 \pm 0.03 \mathrm{~b}$ \\
Nitrate $\left(\mathrm{mgl}^{-1}\right)$ & $1.01 \pm 0.22$ & $0.84 \pm 0.23$ & $0.63 \pm 0.17$ \\
Ammonia $\left(\mathrm{mgl}^{-1}\right)$ & $0.52 \pm 0.12 \mathrm{a}$ & $0.14 \pm 0.68 \mathrm{~b}$ & $0.08 \pm 0.13 \mathrm{~b}$ \\
Phosphate $\left(\mathrm{mgl}^{-1}\right)$ & $0.02 \pm 0.01$ & $0.01 \pm 0.00$ & $0.01 \pm 0.00$ \\
Cholorophyll $\mathrm{a}\left(\mathrm{mg} \mathrm{m}^{-3}\right)$ & $1.27 \pm 0.53$ & $0.84 \pm 0.43$ & $0.10 \pm 0.02$ \\
\hline
\end{tabular}

Different letters (a and b within the row) indicate significant difference between means using Tukey's test at $p<0.05$ 
(Table 2). It was observed that more than $80 \%$ of fish individuals were less than $20 \mathrm{~cm}$ length and $40 \mathrm{~g}$ weight (Fig. 2). A comparison of fish species recorded from previous studies for seagrass and mangrove habitats is given in Table 3. Sixty fish species recorded in the seagrass ecosystem of Lawas was comparatively higher than other seagrass habitats in Malaysia; 35 fish species in Merambong shoals, Johor (Arshad et al., 2001; Aziz et al., 2001) and 22 fish species in Merchang, Terengganu (Arshad et al., 2006; Aziz et al., 2006), however these numbers were lower than 75 fish species reported in Sungai Pulai, Johor (Sasekumar et al., 1989). The number of fish species from the current study was also higher than that in the Kuantan mangrove estuary (Jalal et al., 2012), but more similar to Sibuti mangrove estuary (Hoque et al., 2015). The difference in results may probably be due to different sampling gears, techniques and various intensity of fishing effort at each site (Arshad et al., 2006).
Indirectly, the use of only one mesh size in this study may have restricted the fish species diversity. Hoque et al. (2015) reported that comparatively higher number of fish species/taxa were collected by smaller mesh nets of $2.54 \mathrm{~cm}$ when compared to largest mesh sized nets, $5.08 \mathrm{~cm}$ and $10.16 \mathrm{~cm}$. Further investigations using more nets with different mesh sizes may improve and increase the fish diversity in this seagrass bed.

The higher number of fish species and total number of fish were observed during the intermediate season (48 species, 321 fish), followed by wet season (28 species, 162 fish), and dry season (21 species, 118 fish). The high diversity and total number of fish species during the intermediate may coincide with changing seasonal patterns, creating suitable environmental conditions and utilization of blooming seagrass beds as nurseries and feeding grounds. The seagrass coverage in Lawas were observed to start peaking during the months of February till May,

Table 2 : Species of fish recorded in the seagrass ecosystem in Lawas, Sarawak

\begin{tabular}{|c|c|c|c|c|c|c|c|}
\hline Species & $\mathbf{N}$ & $\mathbf{F}$ & $\mathbf{R}$ & Species & $\mathbf{N}$ & $F$ & $\mathbf{R}$ \\
\hline Lethrinus lentjan (Lacepède, 1802) & 77 & 100 & 19 & Pomadasys argenteus(Forsskål,1775) & 4 & 67 & 1 \\
\hline Thryssa hamiltonii Gray, 1835 & 49 & 67 & 10 & Saurida tumbil (Bloch,1795) & 2 & 33 & 1 \\
\hline Hyporhamphus limbatus (Valenciennes, 1847) & 51 & 67 & 7 & Scomberoides commersonnianus ${ }^{3}$ & 5 & 33 & 1 \\
\hline Gerres erythrourus (Bloch,1791) & 40 & 100 & 7 & Leiognathus fasciatus (Lacepède,1803) & 4 & 67 & 1 \\
\hline Gerres oyena (Forsskål,1775) & 45 & 67 & 6 & Sillago asiatica McKay, 1982 & 4 & 67 & 1 \\
\hline Gnathanodon speciosus (Forsskål,1775) & 29 & 67 & 6 & Rachycentron canadum (Linnaeus, 1766) & 3 & 67 & $<1$ \\
\hline Leiognathus equulus (Forsskål,1775) & 50 & 67 & 5 & Carangoides praeustus $^{4}$ & 3 & 33 & $<1$ \\
\hline Lutjanus fulviflamma (Forsskål,1775) & 16 & 67 & 4 & Carangoides caeruleopinnatus ${ }^{5}$ & 4 & 67 & $<1$ \\
\hline Ostorhinchus fasciatus (White, 1790) & 10 & 33 & 3 & Terapon theraps Cuvier,1829 & 3 & 67 & $<1$ \\
\hline Illisha elongata (Anonymous [Bennett],1830) & 12 & 33 & 2 & Lutjanusjohnii (Bloch,1792) & 2 & 67 & $<1$ \\
\hline Sphyraena jello Cuvier, 1829 & 13 & 100 & 2 & Coilia dussumieri Valenciennes, 1848 & 3 & 33 & $<1$ \\
\hline Scomberomorus commerson ${ }^{1}$ & 15 & 33 & 2 & Megalapsis codryla (Linnaeus,1775) & 2 & 67 & $<1$ \\
\hline Nibea soldado (Lacepède,1802) & 14 & 67 & 2 & Scatophagus argus (Linnaeus, 1766) & 2 & 67 & $<1$ \\
\hline Triacanthus nieuhofii Bleeker,1852 & 14 & 33 & 1 & Chirocentrus dorab (Forsskål,1775) & 1 & 33 & $<1$ \\
\hline Selaroides leptolepis (Cuvier,1833) & 13 & 33 & 1 & Echeneis naucrates Linnaeus, 1758 & 1 & 33 & $<1$ \\
\hline Dussumieria elopsoides Bleeker, 1849 & 13 & 33 & 1 & Tripodichthys blochii (Bleeker, 1852) & 1 & 33 & $<1$ \\
\hline Nuchequula longicornis ${ }^{2}$ & 13 & 33 & 1 & Pomadasys maculatus (Bloch,1793) & 1 & 33 & $<1$ \\
\hline Gerres macracanthus Bleeker,1854 & 10 & 67 & 1 & Trichiurus lepturusLinnaeus, 1758 & 1 & 33 & $<1$ \\
\hline Paraplagusia bilineata (Bloch, 1787) & 5 & 67 & 1 & Arius maculatus (Thunberg,1792) & 1 & 33 & $<1$ \\
\hline Platycephalus indicus(Linnaeus, 1758) & 8 & 100 & 1 & Atherinomorus lacunosus (Forster, 1891) & 1 & 33 & $<1$ \\
\hline Ellochelon vaigiensis (Quoy \& Gaimard,1825) & 4 & 67 & 1 & Alectis indicus(Rüppell,1830) & 1 & 33 & $<1$ \\
\hline Siganusjavus (Linnaeus, 1766) & 5 & 67 & 1 & Anodontostoma chacunda (Hamilton, 1822) & 1 & 33 & $<1$ \\
\hline Hemiramphus far (Forsskål,1775) & 4 & 67 & 1 & Tenualosa macrura (Bleeker,1852) & 1 & 33 & $<1$ \\
\hline AmblygasterBleeker, 1849 & 6 & 67 & 1 & Brevitrygon walga (Müller \& Henle,1841) & 1 & 33 & $<1$ \\
\hline Strongylura strongylura van Hasselt, 1823 & 7 & 67 & 1 & Drepane punctata (Linnaeus, 1758) & 1 & 33 & $<1$ \\
\hline Moolgarda seheli (Forsskål,1775) & 5 & 67 & 1 & Pomadasys kaakan (Cuvier,1830) & 1 & 33 & $<1$ \\
\hline Nemipterus hexodon (Quoy \& Gaimard,1824) & 4 & 67 & 1 & Lactarius lactarius(Bloch \& Schneider,1801) & 1 & 33 & $<1$ \\
\hline Rastrelliger kanagurta(Cuvier,1816) & 3 & 67 & 1 & Upeneussp. Cuvier,1829 & 1 & 33 & $<1$ \\
\hline Atule mate (Cuvier,1833) & 5 & 67 & 1 & Epinephelus coiodes (Hamilton,1822) & 1 & 33 & $<1$ \\
\hline Gazza minuta (Bloch,1795) & 3 & 67 & 1 & Lepturacanthus savala (Cuvier,1829) & 1 & 33 & $<1$ \\
\hline Parameter/Season & Dry & Wet & Int & & & & \\
\hline Total Fish Species & 21 & 28 & 48 & & & & \\
\hline Total Fish Recorded & 118 & 162 & 321 & & & & \\
\hline
\end{tabular}

${ }^{*} \mathrm{~N}$ : total no. of fish recorded; F: frequency (\%); R: relative abundance (\%), Int: Intermediate; ${ }^{1}:\left(\right.$ Lacepède, 1800); ${ }^{2}:$ Kimura, Kimura \& Ikejima,2008; ${ }^{3}$ : Lacepède, $1801 ; ;^{4}:$ (Anonymous [Bennett],1830); : (Rüppell,1830) 
Table 3 : Diversity of fishes from seagrass and mangrove ecosystems in Malaysia

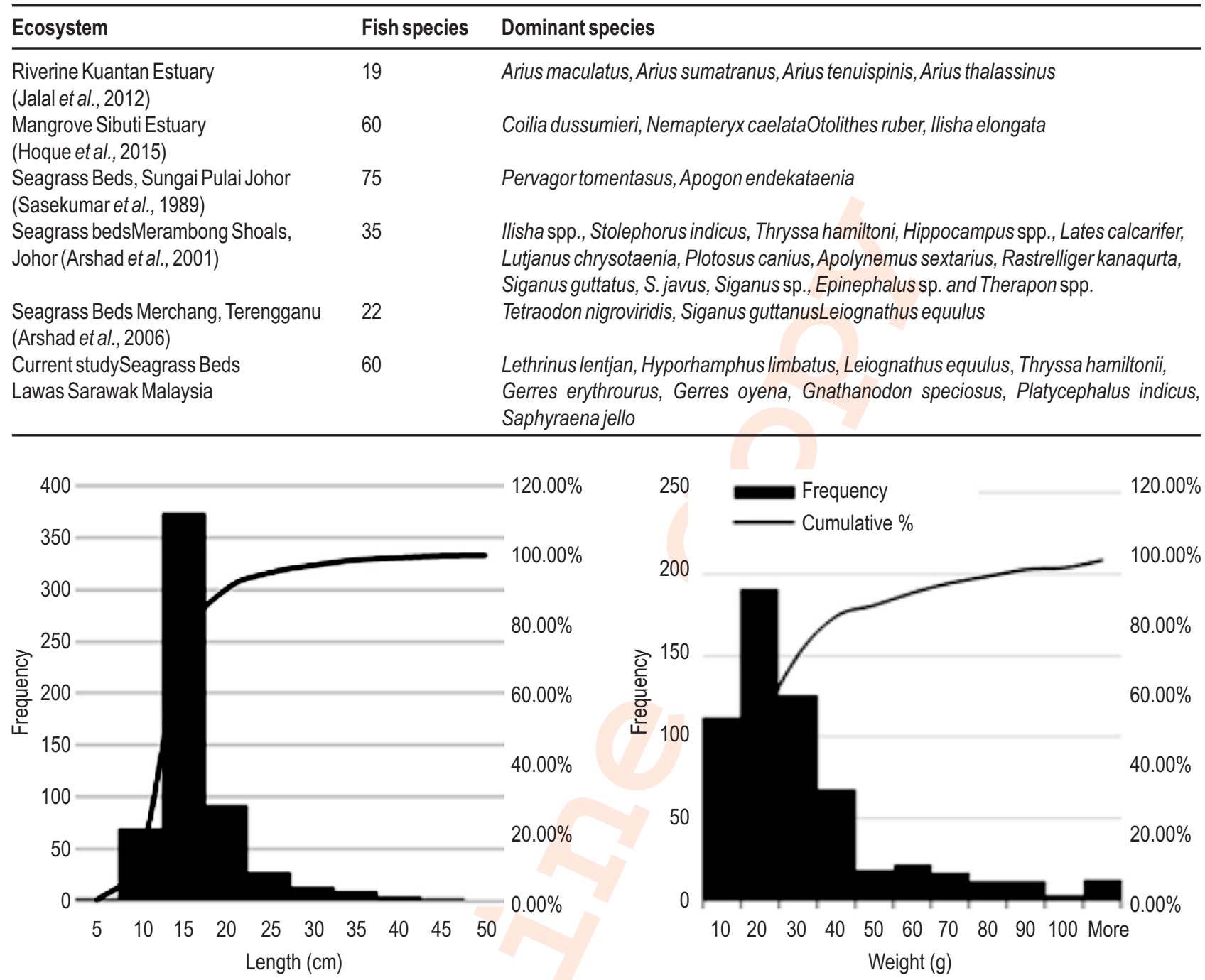

Fig. 2 : Histogram of total length $(\mathrm{cm})$ and weight $(\mathrm{g})$ of fish found in the seagrass ecosystem of Lawas, Sarawak.

right after wet season (Ahmad-Kamil et al., 2013).

The dominant seagrass species in Lawas are represented by Halodulepini folia and Cymodocearo tundata (Ahmad-Kamil et al., 2013). The seagrass species Halodule is known to associate with high presence of fish species (Sundra et al., 1992). In Sungai Pulai seagrass bed of Johor, the abundance of fish larvae peaked during February and March (Intermonsoon), utilizing seagrass beds for spawning (Ara et al., 2011). The dominant fish species observed were Lethrinus lentjan (12.83\%), Hyporhamphus limbatus (8.50\%), Leiognathus equulus (8.33\%), Thryssa hamiltonii (8.17\%), Gerresery throurus $(6.67 \%)$, Gerresoyena (7.5\%), and Gnathanodon speciosus (4.83\%). Four fish species that were found in all seasons were $L$. lentjan, $G$. erythrourus, Platycephalus indicus and Saphyraena jello.
The important species index was employed on the fish relative abundance and frequency data and showed eleven most important species in the seagrass ecosystem (Table 4). L. lentjan is still ranked as having the highest importance (19.28) followed by G. erythrourus (6.73), T. hamiltonii (6.52), H. limbatus (4.82), G. oyena (3.73), G. speciosus (3.71) and L. equulus (3.53). The pink ear emperor fish, L. lentjan, is a very important commercial species for marine fisheries in the subtropical and tropical regions and its juveniles have been reported to inhabit and utilize seagrass and mangrove habitats (Ditch, 2015; Rohani et al., 2013). In the Lawas seagrass bed, L. lentjan was recorded as the most dominant and important fish species, however this was not observed in other seagrass beds (Sasekumar et al., 1989; Arshad et al., 2006; Phinrub et al., 2015). There were also some variations in the dominant species/families of fish recorded from 
Table 4 : Important fish species (ISI index >1.0), mean total length and weight, relative abundance, frequency and important species index (ISI) of fish recorded in the seagrass bed of Lawas, Sarawak

\begin{tabular}{|c|c|c|c|c|c|c|c|c|c|}
\hline \multirow[t]{2}{*}{ Species } & \multirow[t]{2}{*}{ Code } & \multirow{2}{*}{$\begin{array}{l}\text { Mean TL } \\
\text { (cm) }\end{array}$} & \multirow{2}{*}{$\begin{array}{l}\text { Mean weight } \\
\text { (g) }\end{array}$} & \multicolumn{3}{|c|}{ Relative abundance } & \multirow[t]{2}{*}{ Mean $\mathbf{R}$} & \multirow[t]{2}{*}{$\mathbf{F}$} & \multirow[t]{2}{*}{ ISI } \\
\hline & & & & Dry & Wet & Int & & & \\
\hline Lethrinus lentjan & Lle & $13.56 \pm 0.16$ & $34.24 \pm 1.19$ & 0.53 & 0.01 & 0.04 & 0.19 & 100 & 19.28 \\
\hline Gerres erythrourus & $\mathrm{Ge}$ & $11.47 \pm 0.27$ & $25.19 \pm 1.83$ & 0.06 & 0.08 & 0.06 & 0.07 & 100 & 6.73 \\
\hline Thryssa hamiltonii & Th & $12.76 \pm 0.26$ & $13.14 \pm 0.95$ & 0.00 & 0.28 & 0.01 & 0.10 & 67 & 6.52 \\
\hline Hyporhamphus limbatus & $\mathrm{HI}$ & $18.31 \pm 0.38$ & $18.42 \pm 0.97$ & 0.00 & 0.12 & 0.10 & 0.07 & 67 & 4.82 \\
\hline Gerres oyena & Go & $11.74 \pm 0.15$ & $21.58 \pm 1.13$ & 0.00 & 0.06 & 0.11 & 0.06 & 67 & 3.73 \\
\hline Gnathanodon speciosus & Gs & $11.84 \pm 0.13$ & $17.41 \pm 0.50$ & 0.00 & 0.15 & 0.01 & 0.06 & 67 & 3.71 \\
\hline Leiognathus equulus & Le & $9.57 \pm 0.17$ & $9.40 \pm 0.48$ & 0.00 & 0.01 & 0.15 & 0.05 & 67 & 3.53 \\
\hline Lutjanus fulviflamma & Lfl & $15.55 \pm 0.36$ & $53.56 \pm 3.96$ & 0.09 & 0.00 & 0.02 & 0.04 & 67 & 2.42 \\
\hline Sphyraenajello & Sje & $27.51 \pm 1.87$ & $84.30 \pm 8.23$ & 0.03 & 0.03 & 0.02 & 0.02 & 100 & 2.40 \\
\hline Platycephalus indicus & $\mathrm{Pi}$ & $24.96 \pm 1.00$ & $78.38 \pm 7.97$ & 0.01 & 0.01 & 0.02 & 0.01 & 100 & 1.11 \\
\hline Nibea soldado & Ns & $13.45 \pm 0.41$ & $25.58 \pm 0.50$ & 0.00 & 0.01 & 0.04 & 0.02 & 67 & 1.04 \\
\hline
\end{tabular}

${ }^{*}$ R: relative abundance, $S E$ : standard error

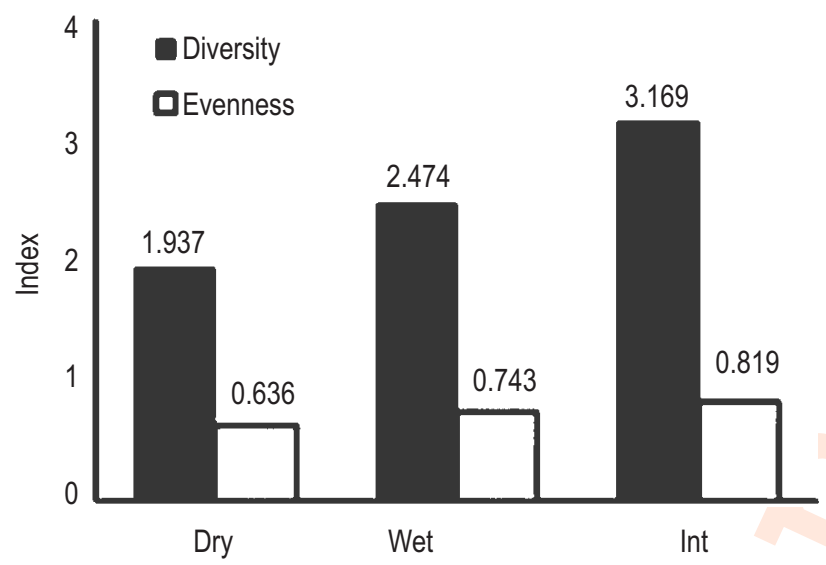

Fig. 3 : Seasonal variation of diversity indices: Shannon-Wiener diversity index $\left(\mathrm{H}^{\prime}\right)$ and Evenness index $(\mathrm{EH})$ of fisheries abundance in the seagrass ecosystem of Lawas, Sarawak.

the seagrass ecosystems compared to other seagrass ecosystems:- Pervagor and Apogon dominance in Sungai Pulai seagrass beds, Johor (Sasekumar et al., 1989), Leiognathidae, Tetraodon nigroviridis dominance in Merchang seagrass bed, Terengganu (Arshad et al., 2006), and Antherinomorus duodecimalis, Sillagosihama and Pelates quadrilineatus in seagrass beds of Sikao bay, Thailand (Phinrub et al., 2015).

Changes in the total and dominant species are often related to geographical locations and different types of seagrass habitats (Arshad et al., 2001). Fish species from the family Gerreidae such as $G$. erythrourus and $G$. oyena are highly dominant temporarily and permanently in seagrass habitats (Phinrub et al., 2015). For instance, another fish species, Illisha elongata, is more dominant in coastal waters and mangrove habitats in Sarawak:- 3.9\% in coastal waters of Bintulu (Nyanti et al., 2014) and 5.8\% in Sibuti river estuary (Hoque et al., 2015), as compared to the current seagrass ecosystem (2\%). I. elongata

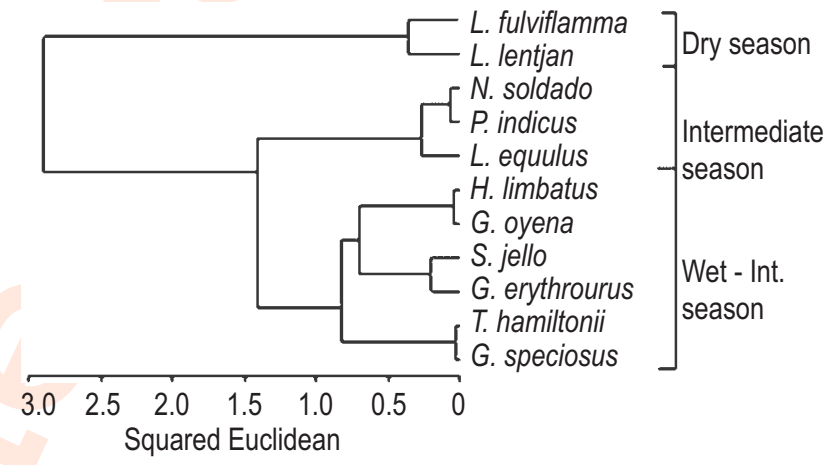

Fig. 4 : Dendogram showing clusters of important fish species assemblages in the seagrass ecosystem of Lawas, Sarawak.

has been described as a mangrove associated fish specie (Abu Hena et al., 2017). In seagrass-mangrove related habitats, transient fishes often move between the seagrass and mangrove areas for feeding (Vaslet et al., 2012).

Univariate analysis showed the diversity index and evenness index of fish assemblage according to seasons (Fig. 3). The diversity index $\left(H^{\prime}\right)$ was lowest during dry season (1.937), followed by wet season (2.474) and intermediate season (3.169). The evenness index showed a similar pattern with the dry season (0.636), followed by wet season (0.743) and intermediate season (0.819), both indices showed increasing trend from dry to intermediate season. The dominant presence of $L$. lentjan and low number of other fish species during dry season are also the cause for low observation of evenness index. The results suggests that the intermediate season plays an important role in terms of fish diversity and abundance in the seagrass ecosystem, and these findings are similar to the findings of other ecosystems studied (Hoque et al., 2015). Larval fishes were also reported to be most abundant in the seagrass habitats during the intermediate season (Ara et al., 2011). 
Cluster analysis revealed three fish species assemblages; dry season fish assemblage comprised of $L$. lentjan and L. fulviflamma, Intermediate season fish species assemblage comprised of Nibeas oldadu, Platycephalus indicus and $L$. equulus, while the wet-intermediate season fish assemblage was represented by $H$. limbatus, G. erythrourus, $T$. hamiltonii, Gerres oyena, Sphyraenajello and Gnathanodon speciosus (Fig. 4). G. erythrourus and Thryssa hamiltonii were reported to be more abundant and associated with the wet season (Phinrub et al., 2014). In this study, the abundance of $L$. lentjan in the seagrasss ecosystem was found abundant during dry season. A similar pattern of distribution was observed when juveniles of $L$. lentjan were found to utilize the seagrassmangrove habitats as feeding grounds during dry season in the seagrass beds of Setiu lagoon Terengganu. Gut content analysis by stable isotope also showed that $L$. lentjan mainly consumed seagrass-based food sources (Le et al., 2018). The abundance of important species (L. lentjan, G. oyena, $L$. erythrourus and $P$. indicus) was found to have correlation (positive or negative) with the physico-chemical: phosphate, dissolved oxygen, temperature and nitrate. Positive correlation was observed for $L$. lentjan with phosphate $(r=0.99 ; p<0.05), L$. equulus with dissolved oxygen $(r=0.99 ; p<0.05)$ and $P$. indicus with temperature $(r=0.99 ; p<0.05)$. G. oyena were negatively correlated with nitrate $(r=-0.99 ; p<0.05)$ content.

The findings suggest that the seagrass ecosystem of Lawas, harbours a rich and diverse group of fish communities including juvenile and adult stages, indicating an important fishery resources habitat, especially for the commercially important fishes such as $L$. lentjan, H. limbatus, L. equulus, G. erythrourus, T. hamiltonii, G. oyena and G. speciosus that inhabit the seagrass ecosystems. The findings of this study provide fundamental baseline knowledge on the fish species inhabiting the seagrass beds of Lawas. This information can be further used for in-depth study of fish population and stocks, seagrassmangrove linkages with economic value to local fishermen communities and can also be used for the Sarawak government plan to convert the Kuala Lawas seagrass beds area into a Marine Park.

\section{Acknowledgments}

The authors extend gratitude to Mr. Othman bin Dinin (Kampung Punang resident and fisherman), Mr. Awangku Nizam Awang Saberan (UPM) and Mr. Meruni Merchang (UPM) for assistance during field sampling. This work was supported by the UPM/800/2/2/4-Geran Putra, Universiti Putra Malaysia.

\section{References}

Abu Hena, M.K., M.H. Idris, A.H. Rajaee and M.A.M. Siddique: Length-weight relationships of three fish species from a tropical mangrove estuary of Sarawak, Malaysia. J. App. Ichthyol., 33, 858-860 (2017).
Abu Hena, M.K., J. Ismail, M.H. Idris and M.K.A. Bhuiyan: Seagrass from Lawas, Sarawak, Malaysia: Diversity and Ecosystem Approach. Paper presented in International Fisheries Symposium, Phu Quoc Island, Vitenman (2016).

Ahmad-Kamil, E.I., R. Ramli, S.A. Jaaman, J. Bali and J. AL-Obaidi: The effects of water parameters on monthly seagrass percentage cover in Lawas, East Malaysia. The Sci. Wor. J., 2013, 1-8 (2013).

Ambak, M.A., M.M. Isa, M.Z. Zakaria and M.A. Gaffar: Fishes of Malaysia. Universiti Malaysia Terengganu. Kuala Terengganu, pp. 334 (2010).

Ara, R., A. Arshad, S.M. Amin, D. Siti Khalijah and A.G. Mazlan: Environment and diversity of ichthyoplankton in the seagrass beds of Sungai Pulai Estuary, Johor, Peninsular Malaysia. J. Food Agricul. Environ., 9, 733-738 (2011).

Ara, R., A. Arshad, S.M. Amin and A.G. Mazlan: Temporal and spatial distribution of larval fish assemblage in different ecological habitat in Johor Strait, Peninsular Malaysia. Asi. J. Ani. Veter. Adva., 8, 5362 (2013).

Arshad, A., B.J. Sidik and Z.M. Harah: Fishes associated with seagrass habitat. In: Aquatic Resource and Environmental Studies of the Straits of Malacca: Current Research and Reviews (Eds.: B. Japar Sidik, A. Arshad, S.G. Tan, S.K. Daud, H.A. Jambari and S. Sugiyama). Malacca Straits Research and Development Centre (MASDEC), Universiti Putra Malaysia, Serdang, Malaysia, pp. 151-162 (2001).

Arshad, A., B.J. Sidik, Z.M. Harah, Y. Suryana and A.G. Mazlan: Fish communities from seagrass bed of Merchang Lagoon, Terengganu, Peninsular Malaysia. Coas. Mar. Sci., 30, 269-275 (2006).

Arshad, A., R. Ara, S.M. Amin, M. Effendi, C. Zaidi and A.G. Mazlan: Influence of environmental parameters on shrimp post larvae in the Sungai Pulai seagrass beds of Johor. Sci. Res. Ess., 6, 55015506 (2011).

APHA: Standard methods for the examination of water and wastewater. $23^{\text {rd }}$ Edn., American Public Health, Washington D.C., pp. 1504 (2017).

Browyn, M.G.: Seagrasses, fish and fisheries. In: Seagrasses: Biology, Ecology and Conservation. (Eds: A.W.D. Larkum, R.J. Orth and C. Duarte). Springer, The Netherlands, pp.503-505 (2006).

Carpenter, K.E. and V.H. Niem: FAO Species identification guide for fishery purposes, The living marine resources of the Western Central Pacific. Vol. 3 and 4, pp. 1397-2790 (1999).

Carpenter, K.E. and V.H. Niem: FAO Species identification guide for fishery purposes. The living marine resources of the Western Central Pacific. Vol. 5 and 6, pp. 2791-4218 (2001).

Connell, D.W. and G.J. Miller: Chemistry and ecotoxicology of pollution. John Wilet and Sons, N.Y. (1988).

Ditch, T.: First comprehensive list of the coral reef fishes of Tunku Abdul Rahman Park, Sabah, Malaysia (Borneo). Check List, 11, 1762, 112 (2015).

Beare, R.J. and P. Tanimomo: Purse seine and encircling net fishing operations in Senegal Guinea, Sierra Leone Ghanna and Benin, FAO LibraryAN: 320319, pp. 92 (1991).

Gandaseca, S., N. Rosli, M.M.P. Ahmad and I.A. Chandra: Effects of land use on river water quality of Awat-Awat Lawas Mangrove Forest Limbang Sarawak Malaysia. Inter. J. Phys. Sci., 9, 386-396 (2014).

Mathias, H.M. and F.M. Yusoff: Seasonal environmental quality variations in a tropical seagrass ecosystem in the Straits of Malacca. Mal. Nat. J., 66, 59-74 (2014).

Mathias, H.M. and F.M. Yusoff: Status of planktonic copepod diversity in 
the Merambong Seagrass Meadow, Johor, Peninsular Malaysia. Int. J. Ecosys., 5, 39-43 (2015).

Hoque, M.M., M.K.A. Hena, M.H. Idris, O.H. Ahmed, A.S.M. Saifullah and M.M. Billah: Status of some fishery resources in a tropical mangrove estuary of Sarawak, Malaysia. Mar. Biol. Res., 11, 834846 (2015).

Hossain, M., S. Othman, J.S. Bujang and M. Kusnan: Net primary productivity of Bruguiera parviflora (Wight \& Arn.) dominated mangrove forest at Selangor, Malaysia. For. Ecol. Manag., 255, 179-82 (2008).

Huijibers, C.M., E.M. Molle and I. Nagelkerken: Post-larval French grunts (Haemulon flavolineatum) distinguish between seagrass, mangrove and coral reef water: Implications for recognition of potential nursery habitats. Fisher. Res., 357, 134-139 (2008).

Jalal, K.C.A., B.Y. Kamaruzzaman, A. Arshad, R. Ara and M.F. Rahman: Diversity and distribution of fishes in tropical estuary, Kuantan, Pahang, Malaysia. Pak. J. Biol. Sci., 15, 576-582 (2012).

Japar, S.B., Z.M. Harah and A. Arshad: Distribution and significance of seagrass ecosystems in Malaysia. Aqu. Ecosys. Hlth. Manage., 9 , 1-14 (2006).

Japar S.B. and Z.M. Harah: Seagrasses in Malaysia. In: Seagrasses: Resource status and trends in Indonesia, Japan, Malaysia, Thailand and Vietnam (Eds.: H. Ogawa, B.J. Sidik and Z.M. Harah). Japan Society for the Promotion of Science (JSPS) and Atmosphere and Ocean Research Institute (AORI), The University of Tokyo. Seizando-Shoten Publishing Co. Ltd. Tokyo Japan, pp. 22-38 (2011).

Juanita, J., H. Nishizawa, H. Marina, Z. Mohd Ihwan, A.J. Saifullah and Z. Xuelei: Utilization of Brunei Bay (Malaysia) as a developmental and foraging habitat for hawksbill turtle (Eretmochelys imbricata). Reg. Stu. Mar.Sci., 16, 304-307 (2017).

Kitamura, H., H. Ishitani, Y. Kuge and M. Nakamoto: Determination of nitrate in freshwater and sea water by a hydrazine reduction method. Suis. Oda. Kenk., 5, 35-42 (1982).

Kovach, W.L.: MVSP - A Multivariate Statistical Package for Windows, ver. 3.1. Kovach Computing Services, Pentraeth, Wales, Great Britain, pp. 133 (1999).

Lee, D.Q., K. Tanaka, Y.S. Hii, Y. Sano, K. Nanjo and K. Shirai: Importance of seagrass-mangrove continuum as feeding grounds for juvenile pink ear emperor Lethrinus lentjan in Setiu Lagoon, Malaysia: Stable isotope approach. J. Sea Res., 135, 1-10 (2018).

Mansor, M.I., H. Kohno, H. Ida, H.T. Nakamura, Z. Aznan and S. Abdullah: Field guide to important commercial marine fishes of the South China Sea, SEAFDEC MFRDMD/SP/2. Malaysia. Kuala Lumpur, pp. 287 (1998).

Matsumuna, M., H. Motomura, K. Matsura, N.A.M. Shazili and M.A. Ambak: Fishes of Terengganu - east coast of Malay Peninsular, Malaysia. National Museum of Nature and Science, University Malaysia Terengganu and Kagoshima University Museum, ix+251 pp (2011).

Mazlan, H., S. Ito, S. Numata, T. Hosaka, M.S. Hossain, S. Misbari, N.N. Yahya and A. Samsudin: Using fisher knowledge, mapping population, habitat suitability and risk for the conservation of dugongs in Johor Straits of Malaysia. Mar. Pol., 78, 18-25 (2017).

Mohsin, A.K.M. and M.A. Ambak: Marine Fishes and Fisheries of Malaysia and Neighboring Countries. Universiti Putra Malaysia Press, Selangor, pp. 744 (1996).

Nagelkerken, I., G. van der Velde, M.W. Gorissena, G.J. Meijera, T. van't Hofc and C. den Hartog: Importance of mangroves, seagrass beds and the shallow coral reef as a nursery for important coral reef fishes, using a visual census technique. Estu., Coa. Shelf Sci., 51, $31-44(2000)$.

Nirmalkumar, J.I., B. George, R.N. Kumar, P.R. Sajish and S. Viyol: Assessment of spatial and temporal fluctuations in water quality of a tropical permanent estuarine system-Tapi, west coast of India. App. Ecol. Environ. Res., 7, 267-276 (2009).

Nyanti, L., G. Jongkar, B. James and I. Norhadi: Fish fauna and fisheries in the coastal waters of Similajau, Bintulu, Sarawak, Malaysia. Kuroshio Sci., 8, 53-57 (2014).

Parsons, T.R., Y. Maita and C.M. Lalli: A manual of chemical and biological methods for seawater analysis. Oxford: Pergamon Press, pp. 173(1984).

Phinrub, W., B. Montien-Art, J. Promya and A. Suvarnaraksha: Fish diversity and fish community in seagrass beds at Ban Pak Klong, Trang Province, Thailand. Int. J. Fishe. Aqu. Stud., 2, 197-201 (2014).

Phinrub, W., B. Montien-Art, J. Promya and A. Suvarnaraksha: Fish diversity and fish assemblage structure in seagrass meadows at Sikao Bay, Trang Province, Thailand. Open J. Ecol., 5, 563-573 (2015).

Rohani, A-P., N.N. Muhammad, L. Husain and L.L. Dmitry: Relationship between the tropical seagrass bed characteristics and the structure of the associated fish community. Open J. Ecol., 3, 331342 (2013).

Rushforth, S.R. and J.T. Brock: Attached diatom communities from the lower Truckee River, summer and fall, 1986. Hydrobiologia, 224, 73, 171-179 (1991).

Saifullah, A.S.M., M.K. Abu Hena, M.H. Idris, A.H. Rajaee and I. Johan: Seasonal variation of water characteristics in Kuala Sibuti estuary in Miri, Sarawak, Malaysia. Malay. J. Sci., 33, 9-22 (2014).

Sasekumar, A., M.U.C. Leh, V.C. Chong, D. Rebeca and M.L. Audrey: A unique mangrove estuary (Eds: S.M. Phang, A. Sasekumar and S. Vinkinaswary). The Sungai Pulai (Johor): Proc: $12^{\text {th }}$ Annual Seminar of the Malaysian Society of Marine Science, Research Priorities for Marine Science in the 90's of Malaysia. MSMS, Kuala Lumpur, pp. 191-211 (1989).

Shannon, C.E. and W. Weaver: The Mathematical Theory of Communications. University of Illinois Press, Urbana, IL, pp. 125 (1963).

Sundra, S., S. Satumanatpan and S. Nateekanjanalarp: A study of the interrelationship of fish communities between coral reefs and seagrass beds. In: Third ASEAN Science and Technology Week Conference Proceedings. Vol. IV, Marine Science, Living Coastal Resources (Eds.: L.M. Chou and C.R. Wilkinson). National University of Singapore, pp.321-325 (1992).

Vaslet, A., D.I. Phillips, C. France, I.C. Feller and C.C. Baldwin: The relative importance of mangrove and seagrass as feeding areas for resident and transient fishes among different mangrove habitats in Florida and Belize: Evidence from dietary and stableisotope analyses. J. Exper. Mar. Biol. Ecol., 434-435, 81-93 (2012).

Wong, N.L.W.S., A. Arshad, F.M. Yusoff, B.J. Sidik and A.G. Mazlan: The epifaunal marine bivalves and macrophytes in Merambong Shoal, Pulai River Estuary, Straits of Malacca. Mala. Nat. J., 66, 42-51 (2014).

Zaleha, K., M.F. Farah Diyana, Y.B. Kamaruzzaman and B.J. Akbar: Meiobenthic community in vegetative areas at Sungai Pulai estuary, Johor, Malaysia. Mala. Nat. J., 67, 1-14 (2015). 